\title{
A Rapid Method Using PCR-Based SCAR Markers for the Detection and Identification of Phoma sclerotioides: The Cause of Brown Root Rot Disease of Alfalfa
}

\author{
R. C. Larsen, Vegetable and Forage Crops Production, Agricultural Research Service, U.S. Department of Agricul- \\ ture, Prosser, WA 99350; C. R. Hollingsworth, University of Wyoming, Laramie 82071; G. J. Vandemark, Vege- \\ table and Forage Crops Production, Agricultural Research Service, U.S. Department of Agriculture, Prosser, WA \\ 99350; M. A. Gritsenko, Washington State University-IAREC, Prosser 99350; and F. A. Gray, University of \\ Wyoming, Laramie 82071
}

\begin{abstract}
Larsen, R. C., Hollingsworth, C. R., Vandemark, G. J., Gritsenko, M. A., and Gray, F. A. 2002. A rapid method using PCR-based SCAR markers for the detection and identification of Phoma sclerotioides: The cause of brown root rot disease of alfalfa. Plant Dis. 86:928-932.

A rapid technique for identification and detection of Phoma sclerotioides, the causal agent of brown root rot of alfalfa, has been developed using polymerase chain reaction (PCR). Amplification products obtained from random amplified polymorphic DNA (RAPD) reactions were cloned and sequenced, and two extended primer sets were designed from the resulting data that were used to detect sequence-characterized DNA markers. A single 499-bp DNA amplification product was consistently obtained from primers PSB $12_{499}$ that was specific for 19 isolates of $P$. sclerotioides but was not produced from Phoma medicaginis or Phoma betae, or from other soilborne pathogens including Aphanomyces euteiches, Rhizoctonia solani, Fusarium oxysporum, Pythium ultimum, or Phytophthora infestans. A 499-bp amplification product was also produced from root tissue known to be infected with the fungus as verified by microscopic examination. A similar PCR product was obtained from soil samples collected from fields with an established infection of $P$. sclerotioides on alfalfa. This PCR-based assay enables detection of $P$. sclerotioides from alfalfa root tissue and in soil samples in a single day, including extraction of DNA, compared with standard methods that require up to 100 days for identification using agar media.
\end{abstract}

Additional keywords: pathogen detection, sequence-characterized amplified region

Phoma sclerotioides G. Preuss ex Sacc. has been associated with winter kill of alfalfa (Medicago sativa L.) and other legume crops in temperate regions with severe winters. The fungus was first reported on forage legumes in Canada in 1933 and identified as Plenodomus meliloti Dearn. \& G.B. Sanford (12). The pathogen has also been found in Nova Scotia, Alaska, and the Yukon regions of Canada (12). P. sclerotioides has earned the com-

Corresponding author: R. C. Larsen

E-mail: rlarsen@tricity.wsu.edu

Mention of a trademark or proprietary product does not constitute a guarantee or warranty of the product by the U.S. Department of Agriculture and does not imply its approval to the exclusion of other products that also may be suitable. This article reports the results of research only.

Accepted for publication 11 April 2002.

Publication no. D-2002-0627-01R

This article is in the public domain and not copyrightable. It may be freely reprinted with customary crediting of the source. The American Phytopathological Society, 2002. mon name brown root rot (BRR) of alfalfa because of the disease symptoms expressed in this host. BRR was first reported in the contiguous United States in 1996 near Farson, WY, after a severe winter resulted in a high mortality rate the following spring in established alfalfa fields $(3,5)$. The pathogen has subsequently been isolated from alfalfa fields in eight counties in Wyoming (3) and was also reported recently from Montana and Idaho (F. A. Gray, unpublished). Hollingsworth suggested that BRR may be present in many of the alfalfa fields (ca. 100,000 ha) in Wyoming and other high-altitude growing areas in the Rocky Mountain region $(1,4)$.

Aboveground symptoms on alfalfa caused by $P$. sclerotioides typically are found in plants at least 3 years old and include stunting and decline. Infected taproots develop dark brown lesions occasionally surrounded by a black border (2). The initially small root lesions coalesce, eventually causing a general rotting of the infected area. Crowns and shoots are often killed as a result of the root infection. Affected plants are generally slow to break dormancy in the early spring. Macroscopic identification of BRR on alfalfa roots can be difficult, as the symptoms are readily confused with root rot symptoms caused by Phytophthora medicaginis (2). In addition, a complex of other soilborne pathogens including species of Rhizoctonia, Aphanomyces, and Pythium also infect alfalfa and may mask symptoms caused by $P$. sclerotioides.

Detection of fungal pathogens with molecular and polymerase chain reaction (PCR) techniques has been used successfully by others $(6-9,13,14)$. Willits and Sherwood (14) were able to detect Ustilago hordei on barley leaves by PCR. Vandemark et al. (13) recently developed a PCR protocol using sequence characterized amplified regions (SCARs) (10) for identification of Aphanomyces euteiches in pea roots and A. cochlioides in sugar beets. Because the isolation, growth, and subsequent identification of $P$. sclerotioides is time-consuming, requiring up to 100 days after transfer to agar media before conidia are released from pycnidia (12), the objective of this work was to develop a rapid and efficient method using SCARs to unambiguously detect the presence of $P$. sclerotioides in infected alfalfa tissue and in soil samples collected from alfalfa fields.

\section{MATERIALS AND METHODS}

DNA extraction. Eighteen isolates of $P$. sclerotioides collected from six regions in Wyoming (4), including Boulder, Farson, Eden, Laramie, Lyman, and Saratoga, and a Canadian isolate obtained from the American Type Culture Collection (ATCC 56515) were used in this study. Only slight morphological variability, primarily mycelial pigmentations, existed among each of the 18 Wyoming isolates and the Canadian isolate. The fungal cultures were grown on potato dextrose agar (PDA) (Difco Laboratories, Detroit, MI) in the dark and maintained in a growth chamber adjusted to $15.6 \pm 1.0^{\circ} \mathrm{C}$ for 30 to 45 days. Mycelium was then separated from the agar substrate using a sterile spatula and desiccated overnight under vacuum in a SpeedVac SC100 system (Savant Instruments, Farmingdale, 
NY). Total nucleic acid was extracted from the dried mycelium using a modification of the method described by Vandemark et al. (13). Lyophilized mycelium (0.2 g) was macerated in liquid nitrogen using a mortar and pestle. The ground mycelium was hydrated for $10 \mathrm{~min}$ at room temperature in $3 \mathrm{ml}$ of extraction buffer (200 mM Tris, $\mathrm{pH}$ $8.5,250 \mathrm{mM} \mathrm{NaCl}, 25 \mathrm{mM}$ EDTA, and $0.5 \%$ sodium dodecyl sulfate [SDS]) and the DNA extracted with an equal volume of phenol/chloroform. The nucleic acid was precipitated with $0.1 \mathrm{vol}$ of $0.3 \mathrm{M}$ sodium acetate, $\mathrm{pH} 5.5$, and 2.5 vol of ethanol. After centrifugation for $10 \mathrm{~min}$ at $10,000 \times g$, the pellet was washed with $70 \%$ ethanol and dried briefly under vacuum. The pellet was resuspended in $100 \mu \mathrm{g}$ of RNase H (Sigma, St. Louis, MO) per ml and incubated $15 \mathrm{~min}$ at $37^{\circ} \mathrm{C}$ to remove RNA. The suspension was extracted twice with equal volumes of phenol/chloroform, followed by a final wash in an equal volume of chloroform. The supernatant was precipitated in ethanol as described above, and the final DNA pellet was resuspended in Tris-EDTA (10 mM Tris, $\mathrm{pH} \mathrm{8.0,} \mathrm{and} 1$ mM EDTA). All DNA preparations were adjusted to $10 \mathrm{ng} / \mu \mathrm{l}$ using a spectrophotometer with ultraviolet absorbance at 260 nm. DNA was also extracted from other soilborne fungi including Aphanomyces euteiches, Rhizoctonia solani, Fusarium oxysporum, Pythium ultimum, and Phytophthora infestans as described above to provide experimental controls. In addition, DNA from two isolates of Phoma medicaginis and four isolates of Phoma betae was used to verify specificity of primers to P. sclerotioides.
Six-month-old alfalfa plants were inoculated with $P$. sclerotioides on infested barley grains as described by Hollingsworth (4). Briefly, two barley grains were placed against the taproots approximately $2.5 \mathrm{~cm}$ below the soil surface in December. Cotton was placed over the inocula and the soil replaced. Plants were placed outdoors for a total of 15 months winter exposure (January to May) at Laramie, WY, during a 3year period. The average soil temperature for each of the consecutive 5-month winter periods was $0.6,2.3$, and $0.6^{\circ} \mathrm{C}$, respectively. Plants were subsequently returned to the greenhouse and maintained at average air temperatures of $21^{\circ} \mathrm{C}$ day and $15^{\circ} \mathrm{C}$ night. Roots of inoculated plants were washed free of soil using tap water and blotted dry. Root tissue from noninoculated alfalfa roots was used as healthy controls. In addition, alfalfa plants naturally infected with $P$. sclerotioides were collected from fields in Farson, WY, during the 2001 growing season. Lesions from roots exhibiting symptoms of BRR were excised using a sterile scalpel. Total DNA was extracted from approximately $200 \mathrm{mg}$ of root tissue per plant using the Fast DNA kit (Bio 101, Carlsbad, CA) according to the manufacturer's instructions. The final DNA preparation was diluted 1:100 using sterile distilled water and stored at $-20^{\circ} \mathrm{C}$.

Soil samples from greenhouse plants were collected near roots previously inoculated with $P$. sclerotioides as described above (4). Soil samples were also collected from a grower's fields near Farson, WY, where alfalfa plants exhibiting symptoms of BRR were observed. Soil samples used as noninfested negative controls were collected, and 5- to 10-g aliquots were autoclaved at $121^{\circ} \mathrm{C}$ at $15 \mathrm{psi}$ for $20 \mathrm{~min}$. DNA was extracted from a 500-mg subsample of each soil sample using the Ultra-Clean DNA soil extraction kit (Mo-Bio, Solana Beach, CA) according to the manufacturer's protocol.

Screening for random amplified polymorphic DNA (RAPD) markers and detection of SCARs. DNA from each fungal isolate was screened for RAPD markers generated by random decamer primers (Operon, Inc., Alameda, CA) and amplified by PCR in $25-\mu l$ reactions using the method described by Vandemark et al. (13). Reactions were resolved by agarose gel $(1.4 \% \mathrm{wt} / \mathrm{vol})$ electrophoresis, stained with ethidium bromide, visualized under ultraviolet light, and recorded with an AlphaImager 2000 (Apha Innotech, San Leandro, CA). Markers that were selectively amplified from all 19 isolates of $P$. sclerotioides but not from the other pathogens screened were excised from agarose gels. DNA was purified from the gel bands using GeneClean (Bio 101 Inc., Vista, CA) and cloned into the vector pCR2.1 Topo using the Topo TA cloning kit (Invitrogen, Carlsbad, CA) according to the manufacture's instructions. Plasmid DNA was purified from Escherichia coli using alkaline lysis (11), and clones containing the PCR product were identified by digestion with $E c o \mathrm{R} 1$ and visualized by agarose gel electrophoresis. The DNA products were sequenced using the dideoxy-chain termination method, and extended primers were subsequently designed based on the terminal sequences of the cloned markers for
A

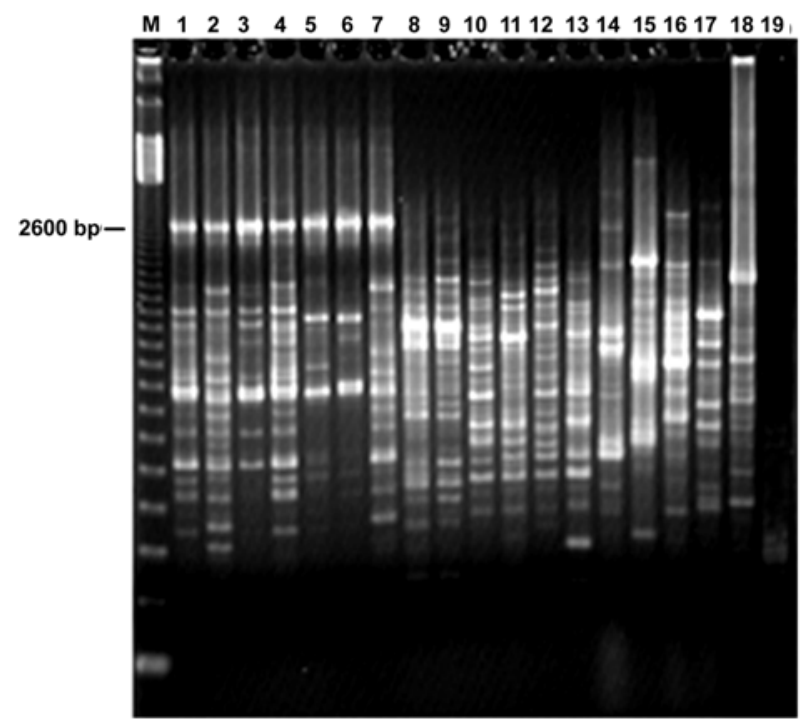

B

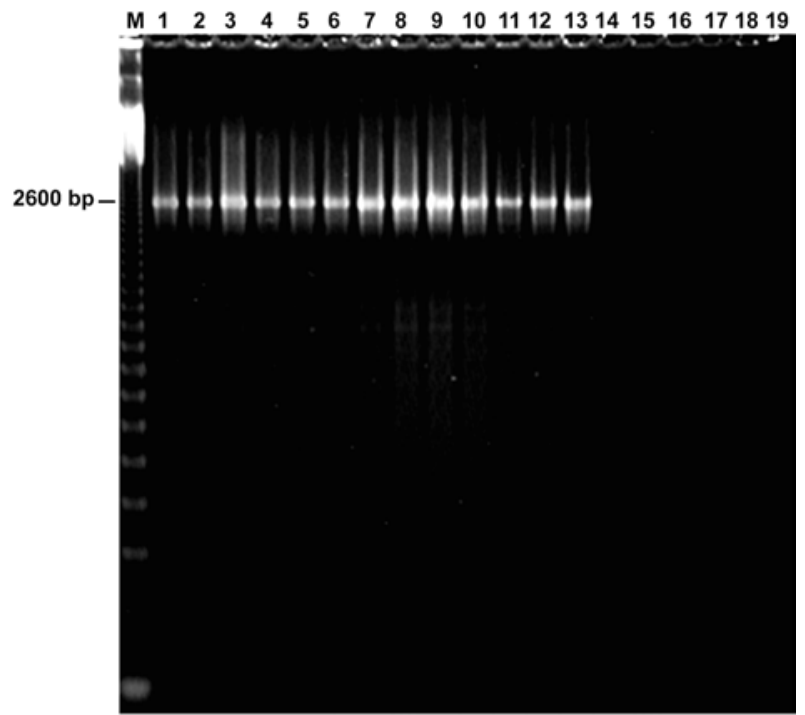

Fig. 1. A, Agarose gel showing amplification products from polymerase chain reaction (PCR) of genomic DNA using the random amplified polymorphic DNA (RAPD) decamer primer OpC15. Marker indicates the 2.6-kb fragment of Phoma sclerotioides sequenced to design SCAR primers PSC15 2600 . B, Amplification products from PCR of genomic DNA of $P$. sclerotioides using the sequence-amplified characterized region (SCAR) primer pair OpC15 2600 . Lanes 1 to 7: isolates of P. sclerotioides from Farson, Lyman, Eden, Boulder, Saratoga, and Laramie regions in Wyoming; and Canada (ATCC), respectively. Lanes 8 and 9: Phoma medicaginis, lanes 10 to 13: Phoma betae, lane 14: Aphanomyces euteiches, lane 15: Rhizoctonia solani, lane 16: Fusarium oxysporum, lane 17: Pythium ultimum, lane 18: Phytophthora infestans, lane 19: water control. 
conversion of the selected RAPD marker to a SCAR primer pair.

SCAR reactions. DNA (50 ng) extracted from pure mycelial cultures, root tissue, or soil samples was used in $25-\mu 1$ PCR reactions containing $15 \mathrm{mM}$ Tris, $\mathrm{pH}$ 8.0, $2.5 \mathrm{mM} \mathrm{MgCl}_{2}, 100 \mathrm{mM}$ each of dATP, dCTP, dGTP, and dTTP, $200 \mathrm{mM}$ of each of the two respective SCAR primers, and 2.5 units of AmpliTaq Gold DNA polymerase (Applied Biosystems, Foster City, CA). Thermocycling parameters were optimized and a final profile was employed that consisted of a single cycle of $9 \mathrm{~min}$ at $95^{\circ} \mathrm{C} ; 35$ cycles of $1 \mathrm{~min}$ at $94^{\circ} \mathrm{C}, 1 \mathrm{~min}$ at $70^{\circ} \mathrm{C}$, and $1 \mathrm{~min}$ at $72^{\circ} \mathrm{C}$; and a final extension for $7 \mathrm{~min}$ at $72^{\circ} \mathrm{C}$. SCAR reactions using DNA extracted from native field soil samples were carried out as described above except that the 35 cycle PCR procedure was increased to 40 cycles.

\section{RESULTS}

RAPD primer analysis. Thirty-nine RAPD decamer primers were evaluated in PCR reactions. Primers OpB1, OpB4, OpB12, OpC12, and OpC15 selectively amplified conserved DNA fragments from all isolates of $P$. sclerotioides. Products from two of the decamer primers that produced RAPD markers were selected as candidates for SCAR primers. Primer OpC15 produced an amplification product of approximately $2.6 \mathrm{kbp}$ specific to each of the 19 isolates of $P$. sclerotioides (Fig. 1A). Primer OpB12 produced an amplification product consisting of 499 bases also unique to $P$. sclerotioides (Fig. 2A). The 2.6-kbp and 499-bp fragments were not amplified from DNA of the other soilborne fungal pathogens A. euteiches, $R$. solani, $F$. oxysporum, $P$. ultimum, or $P$. infestans, or from the isolates of $P$. betae or $P$. medicaginis. Sequence data obtained from the cloned 2.6-kbp and 499-bp amplification products were used to design the SCAR primers used in all subsequent experiments and were designated PSC15 2600 and PSB12 499 , respectively. The extended SCAR sequences are illustrated below, and the underlined sequence represents the original primer used in RAPD reactions.

PSC $15_{2600}$

PSC15-FS-30 5' GACGGATCAGCCCAC GAAGGACCTTAACGC $3^{\prime}$

PSC15-RS-24 5' GACGGATCAGGTAGG GATACCCGC $3^{\prime}$

PSB12 499

PSB12-FS-24 5' CCTTGACGCACAGAG AATGATTGG $3^{\prime}$

PSB12-RS-26 5' CCTTGACGCATGTTA GCATAAAATCC 3'

SCAR detection and analysis. The SCAR primer pair PSC15 2600 amplified a single SCAR of $2.6 \mathrm{kbp}$ from each of the 19 isolates of $P$. sclerotioides in all experiments (Fig. 1B). In addition, a SCAR identical in size was detected from isolates of $P$. betae and $P$. medicaginis. SCAR primer PSB12 499 produced a single amplification product from each of the $P$. sclerotioides isolates (Fig. 2B) but not from isolates of $P$. betae or P. medicaginis. Amplification products using SCAR primers $\mathrm{PSC}_{15} 5_{260}$ or PSB12 499 were not produced from DNA isolated from A. euteiches, $R$. solani, $F$. oxysporum, $P$. ultimum, or $P$. infestans. This suggests that PSB $12_{499}$ is highly specific to $P$. sclerotioides, while $\mathrm{PSC} 15_{2600}$ is specific to several different Phoma species.

Detection of $P$. sclerotioides from infected roots. Roots of alfalfa plants in the greenhouse exhibiting symptoms of BRR as well as roots from alfalfa plants naturally infected in the field were also evaluated by SCAR primers PSB $12_{499}$. The primers successfully amplified a single PCR product from all roots infected with $P$. sclerotioides that comigrated with the amplification product in the positive control. The PCR reactions did not produce products from root samples used as healthy controls (Fig. 3). Results of the PCR experiments were validated by subculturing root samples on PDA and subsequent identification of the fungal organism by microscopic examination. Fungal cultures were not obtained from asymptomatic alfalfa roots.

Detection of $P$. sclerotioides from soil samples. SCAR primers PSB $12_{499}$ amplified DNA products of the expected size from greenhouse soil samples artificially infested with $P$. sclerotioides. In addition, SCARs were produced from field soil samples collected from the rhizosphere of alfalfa plants exhibiting typical symptoms of BRR (Fig. 4). No amplification products were produced from autoclaved soil. In most cases, optimum results were obtained in PCR reactions when the DNA was diluted 1:10 with sterile water. Tissue excised from symptomatic roots of plants grown in the fields where positive soil samples were taken was microscopically examined and found to be infected with the pathogen.
A

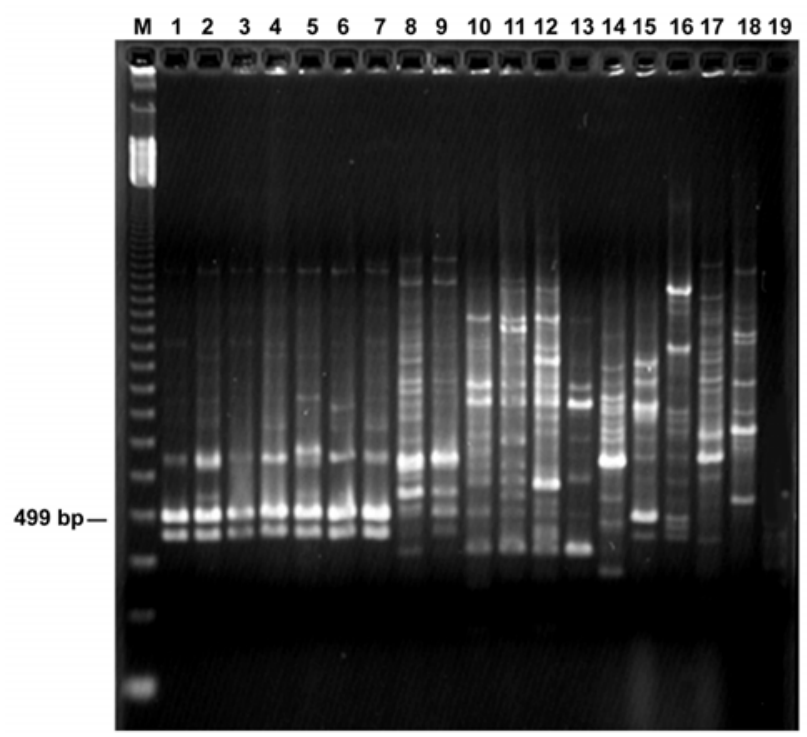

B

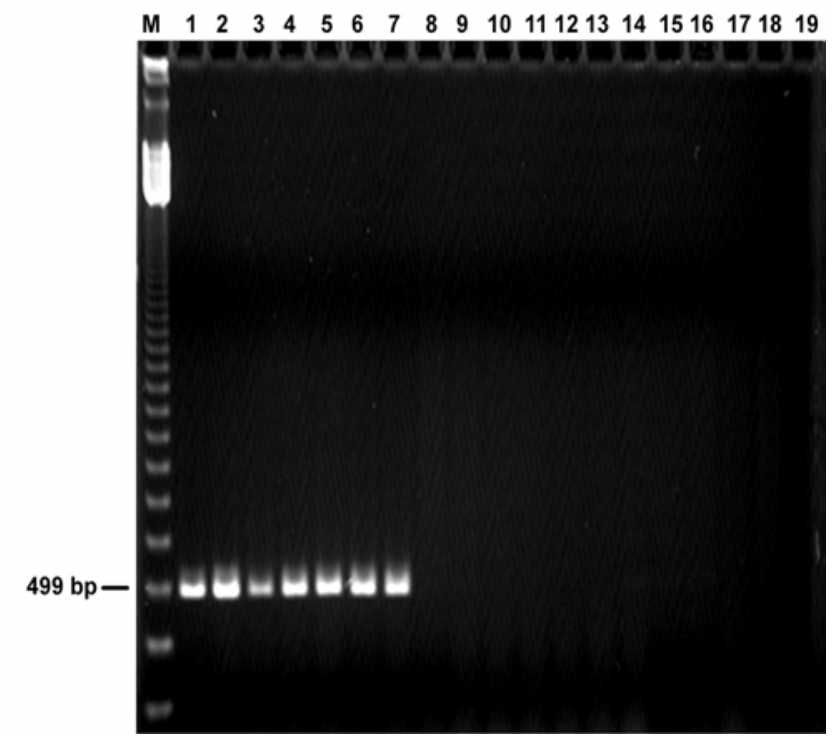

Fig. 2. A, Agarose gel showing amplification products from polymerase chain reaction (PCR) of genomic DNA of Phoma sclerotioides using the random amplified polymorphic DNA (RAPD) decamer primer OpC12. Marker indicates the 499-bp fragment that was sequenced to design SCAR primer PSC12 499 . B, Amplification products from PCR of genomic DNA of $P$. sclerotioides using the sequence-amplified characterized region (SCAR) primer pair PSC12 499 . Lanes 1 to 7: isolates of P. sclerotioides from Farson, Lyman, Eden, Boulder, Saratoga, and Laramie regions in Wyoming; and Canada (ATCC), respectively. Lanes 8 and 9: Phoma medicaginis, lanes 10 to 13: Phoma betae, lane 14: Aphanomyces euteiches, lane 15: Rhizoctonia solani, lane 16: Fusarium oxysporum, lane 17: Pythium ultimum, lane 18: Phytophthora infestans, lane 19: water control. 


\section{DISCUSSION}

$P$. sclerotioides is a difficult pathogen of alfalfa to detect rapidly using standard methods of culturing infected tissue on agar media, primarily due to the long growth periods necessary for production of fungal fruiting structures. Sixty to 100 days are typically required before characteristic fruiting structures are produced on agar media (12). We have designed SCAR primers that can detect the presence of $P$. sclerotioides in infected alfalfa roots or infested soil samples in a single day. The SCAR primer PSB $12_{499}$ produced a single diagnostic DNA amplification product consisting of $499 \mathrm{bp}$ from all 18 isolates of $P$. sclerotioides collected from six regions in Wyoming and from one ATCC isolate of P. sclerotioides from Canada. The SCAR primer pair did not amplify this DNA product from the other Phoma species evaluated nor from other soilborne pathogens included in this study.

SCAR primers $\mathrm{PSC} 15_{2600}$ amplified a single DNA product from three species of Phoma, including P. sclerotioides, $P$. medicaginis, and $P$. betae. It is possible that this SCAR may be diagnostic for other species of Phoma. The primers were not exhaustively tested on all available species of the organism, as such an evaluation was beyond the scope of this research. We found it interesting that the OpC15 RAPD primer produced the 2.6-kbp amplification product only in isolates of P. sclerotioides. However, with the design of PSC15 2600 , SCARs were consistently produced from all three Phoma species. Although the entire 2.6kbp region was not sequenced in this study, it is surmised that an insufficient number of nucleotide bases in RAPD primer OpC15 were present to result in amplification of the 2.6-kbp product in the three species. Extension of the forward primer to 30 bases and the reverse primer to 24 bases in the design of PSC15 1500 may have resulted in a sufficient number of base pair matches to produce the 2.6-kbp product from all three Phoma species tested.

The PSB $12_{499}$ SCAR primers produced a single amplification product from DNA isolated from infected alfalfa roots that were sampled from fields in Farson, WY, and from roots experimentally inoculated with $P$. sclerotioides. Isolation and identification of the fungal pathogen in experiments using agar media corroborated the results using SCARs. In some experiments (data not shown), P. sclerotioides was not recovered on PDA from symptomatic root tissue even though the PCR primers generated a 499-bp SCAR from the same root tissue. This suggests that the SCAR primer pairs provide the advantage of greater sensitivity over standard isolation techniques.

There is currently no efficient method available for isolating and concentrating pycnidia or pycnosclerotia of $P$. sclerotioides from soil, nor has a selective medium been developed for this pathogen.

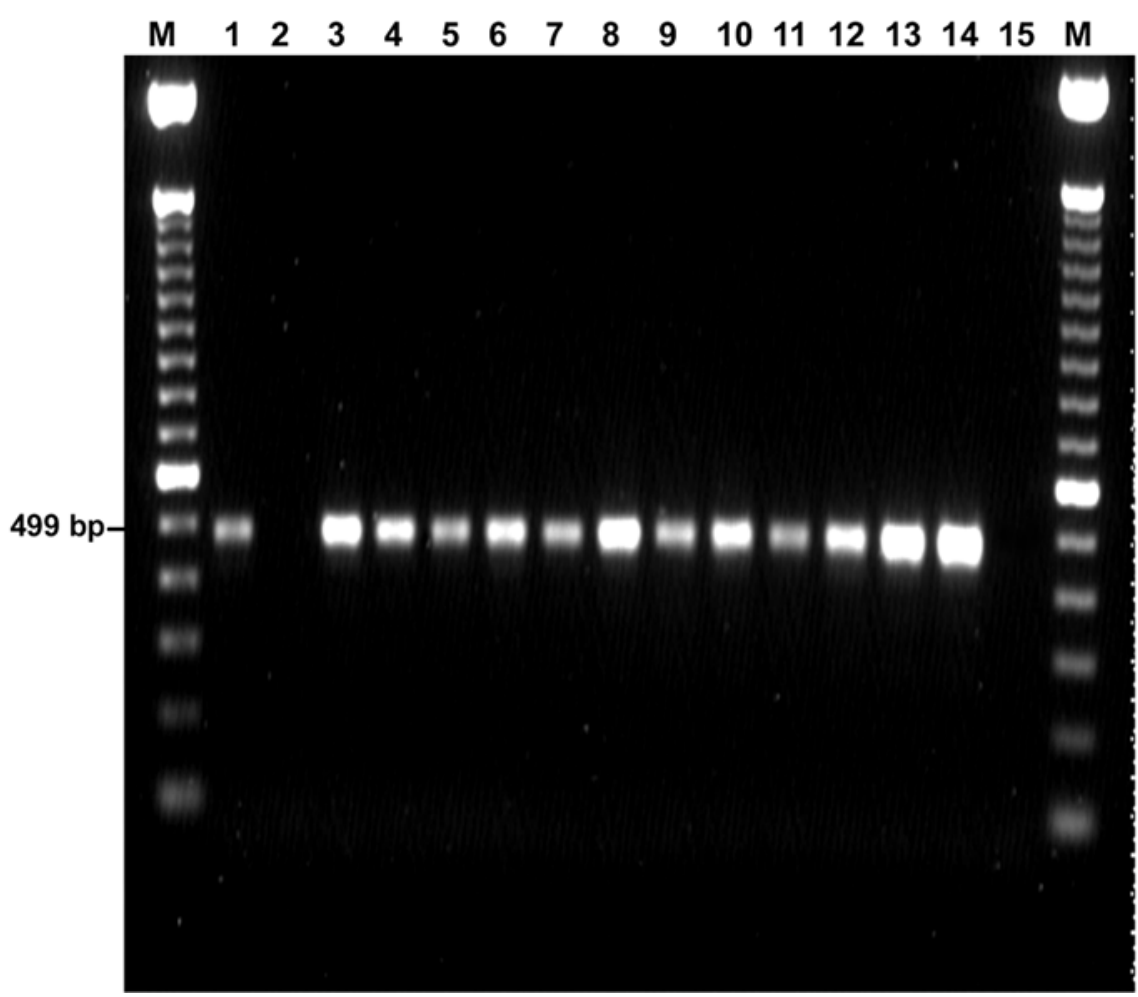

Fig. 3. Detection of Phoma sclerotioides from alfalfa roots. Agarose gel showing amplification products produced by sequence-amplified characterized region (SCAR) primer pair PSC12 499 in polymerase chain reactions. Lane M: 100-bp ladder, lane 1: P. sclerotioides genomic DNA, lane 2 . healthy alfalfa root, lanes 3 to 8: root samples from plants inoculated with $P$. sclerotioides and maintained under greenhouse conditions (see text), lanes 9 to 14: roots sampled randomly from alfalfa fields in Farson, WY, lane 15: water control.

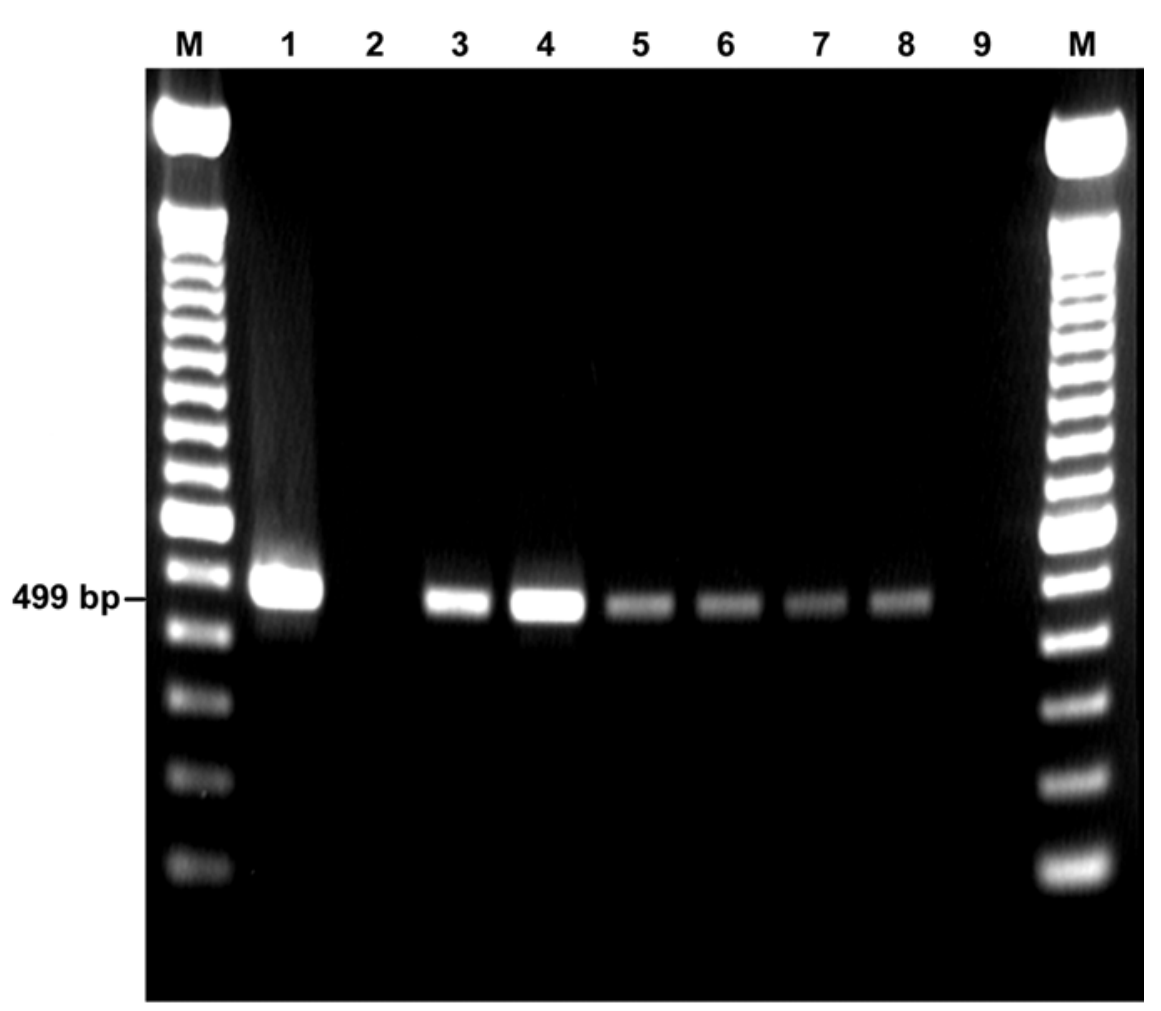

Fig 4. Detection of Phoma sclerotioides from soil samples. DNA was extracted from 500-mg aliquots. Agarose gel showing amplification products produced by sequence-amplified characterized region (SCAR) primer pair PSC $12_{499}$ in polymerase chain reactions. Lane M: 100-bp ladder, lane 1: P. sclerotioides genomic DNA, lane 2: noninfested soil, lanes 3 and 4: greenhouse soil samples from pots containing alfalfa plants infected with $P$. sclerotioides, lanes 5 to 8: random soil samples collected from alfalfa fields in Farson, WY, lane 9: water control. 
The SCAR PSB $12_{499}$ primers detected $P$. sclerotioides in soil samples known to be infested with the pathogen based on isolation of the pathogen from alfalfa roots and the fungal thallus on agar media. Sufficient DNA of the pathogen was available in 0.5g soil samples that the 499-bp SCAR product was routinely obtained. In several experiments, the final DNA suspension required additional dilutions before the SCAR product could be visualized adequately on agarose gels. Inhibitors of the PCR reaction may have been present in the samples after DNA extraction, or the final DNA suspension may have been so highly concentrated as to interfere with the reaction.

The detection system described in this study offers a rapid and accurate method for unambiguous identification of $P$. sclerotioides in infected alfalfa roots or in infested soil. The method is highly sensitive and can detect DNA of the pathogen at concentrations of $2 \mathrm{pg}$ or less (data not shown). However, because we were interested in developing a rapid diagnostic test for detection of the pathogen, DNA concentrations of random samples used in our detection assays were not routinely quantified to provide optimum results. Dilution of the extracted DNA by 1:100 was sufficient in all cases for the primers to produce the 499-bp SCAR product from alfalfa roots that were infected with $P$. sclerotioides. This diagnostic assay may be used to detect the presence of P. scle- rotioides in fields currently planted to alfalfa or in fields considered for planting with alfalfa in the future. Furthermore, this assay may be valuable for evaluating alfalfa germ plasm being screened for resistance to BRR, by greatly reducing the time required to assay large numbers of individual plants.

\section{ACKNOWLEDGMENTS}

We thank J. Gerik, USDA-ARS, for isolates of Phoma betae; S. Fitzpatrick, Applied Genetics, West Salem, WI, for isolates of Phoma medicaginis; J. Kraft, USDA-ARS (retired), for isolates of Aphanomyces euteiches; and L. du Toit, Washington State University, Mt. Vernon, for suggestions and critical review of the manuscript.

\section{LITERATURE CITED}

1. Davidson, J. G. N. 1990. Brown root rot. Pages 29-31 in: Compendium of Alfalfa Diseases. 2nd ed. D. L. Stuteville and D. C. Erwin, eds. American Phytopathological Society, St. Paul, MN.

2. Gray, F. A., Heald, T. E., Hollingsworth, C. R., and Koch, D. W. 1997. Brown root rot caused by Phoma sclerotioides, a new disease of alfalfa in the U.S. Page 24 in: Proc. West. Alfalfa Improv. Conf., 10th. Davis, CA.

3. Gray, F. A., Hollingsworth, C. R., Koch, D., and Heald, T. 1999. Brown root rot of alfalfa. Univ. Wyo. Coll. Agric., Agric. Exp. Stn. Ext. Bull. 1. University of Wyoming, Laramie.

4. Hollingsworth, C. R. 1999. Biology and management of brown root rot, Phoma sclerotioides, of alfalfa. M.S. thesis. University of Wyoming, Laramie.

5. Hollingsworth, C. R., and Gray, F. A. 1999. First report of brown root rot on alfalfa caused by Phoma sclerotioides in the Conti- nental United States. Plant Dis. 83:1071.

6. Lee, S. B., White, T. J., and Taylor, J. W. 1993. Detection of Phytophthora species by oligonucleotide hybridization to amplified ribosomal DNA spacers. Phytopathology 83:177-181.

7. Levesque, C. A., Harlton, C. E., and de Cock, A. W. A. M. 1998. Identification of some oomycetes by reverse dot blot hybridization. Phytopathology 88:213-222.

8. Levesque, C. A., Vrain, T. C., and De Boer, S. H. 1994. Development of a species-specific probe for Pythium ultimum using amplified ribosomal DNA. Phytopathology 84:474-478.

9. Malvick, D. K., Grau, C. R., and Percich, J. A 1998. Characterization of Aphanomyces euteiches strains based on pathogenicity tests and random amplified polymorphic DNA analysis. Mycol. Res. 102:465-475.

10. Paran, I., and Michelmore, R. W. 1993. Development of reliable PCR-based markers linked to downy mildew resistance genes in lettuce. Theor. Appl. Genet. 85:985-993.

11. Sambrook, J., Fritsch, E. F., and Maniatis, T., eds. 1989. Molecular Cloning: A Laboratory Manual. 2nd ed. Cold Spring Harbor Laboratory, Cold Spring Harbor, NY.

12. Sanford, G. B. 1933. A root rot of sweet clover and related crops caused by Plenodomus melioto Dearness \& Sanford Can. J. Res. Sect. C 8:337-348.

13. Vandemark, G. J., Kraft, J. M., Larsen, R. C., Gritsenko, M. A., and Boge, W. L. 2000. A PCR-based assay by sequence-characterized DNA markers for the identification and detection of Aphanomyces euteiches. Phytopathology 90:1137-1144.

14. Willits, D. A., and Sherwood, J. E. 1999. Polymerase chain reaction detection of Ustilago horde $i$ in leaves of susceptible and resistant barley varieties. Phytopathology 89:212-217. 